\title{
Bangladesh's Emergence as a Ready-Made Garment Export Leader: An Examination of the Competitive Advantages of the Garment Industry
}

\author{
Ishtehar Sharif Swazan ${ }^{1}$ D . Debanjan Das ${ }^{1}$ (D)
}

Received: 4 October 2021 / Accepted: 21 January 2022 / Published online: 9 February 2022

(c) The Author(s) under exclusive licence to Global Institute of Flexible Systems Management 2022

\begin{abstract}
Bangladesh is the second-largest ready-made garment (RMG) manufacturer and exporter in the world. The RMG industry of Bangladesh has become one of the fastest-growing industries globally since the 1990s and is the main source of its foreign earnings for the last three decades. To gain an in-depth understanding of the Bangladeshi RMG industry's competitive advantages, a semi-structured qualitative interview approach was employed with 14 executives currently working in the Bangladeshi RMG industry. Porter's (1990) diamond model of national competitive advantage was adopted as the study's conceptual framework. Interpretation of the study data revealed four key competitive advantages for the Bangladeshi RMG industry: (a) price, (b) on-time delivery, (c) quality, and (d) product advantages. This study explores the RMG industry of Bangladesh and identifies the competitive advantages from the executive's perspective, thereby adding value and originality to the academic literature.
\end{abstract}

Keywords Bangladesh garment industry · Porter diamond · Competitive advantage · Qualitative interview

\section{Introduction}

In the last 25 years, the ready-made garments (RMG) industry has been the most significant source of foreign earnings for Bangladesh (Das et al., 2018; Rahman, 2021; Zaman, 2021). More than $84 \%$ of the total export earnings in 2019-2020 came from garment exports which are both a comforting and alarming issue (BGMEA, 2021a, 2021b; Islam, 2021). Comforting because it shows that the export growth of the RMG industry is stable and alarming because of the country's dependency on one source of foreign income. Attaining competitive advantages in garment exports would provide stability to the RMG industry of Bangladesh and help it become more successful.

Continued growth in the apparel industry has helped Bangladesh to maintain steady economic growth (Ahlquist $\&$ Mosley, 2021; Zaman, 2021). The salary structure of the Bangladeshi apparel industry is the major reason the country

Ishtehar Sharif Swazan

ishtehar.swazan@gmail.com

1 Fashion Dress and Merchandising, West Virginia University, 704 G Allen Hall, 355 Oakland Street, PO BOX 6124, Morgantown, WV 26506-6124, USA is considered a global apparel sourcing hub as the current monthly minimum wage is USD 97 (Chandra \& Ferdaus, 2020; Paul, 2018). Meanwhile, the minimum monthly wage in China ranges from USD 162 to USD 358 (Koty \& Zhou, 2019). This lower wage attracts foreign buyers to source from Bangladesh, leading to an apparel export value of USD 33.07 billion in 2019 (BGMEA, 2021a, 2021b). Europe and the United States of America (USA) are the major exporting destinations comprising $80 \%$ of the country's total apparel exports in 2019. Bangladesh's apparel exports to the European Union (EU) in 2019 were USD 20.42 billion and to the USA was USD 6.02 billion (BGMEA, 2021a, 2021b). The country also exports apparel products to Canada, Japan, Australia, China, India, Brazil, Chile, Mexico, Russia, and Turkey (Menzel \& Woodruff, 2021).

Today, Bangladesh holds the second position in garment exporting while China remains the first for the last few decades (Nadiruzzaman et al., 2021; Zaman, 2021). Bangladesh is also seen as the next sourcing destination to replace China due to its large labor force, low wages, and modern manufacturing facilities (Islam, 2021; Menzel \& Woodruff, 2021; Rahman, 2021). However, researchers (Ahlquist \& Mosley, 2021; Ahmed, 2009; Bair et al., 2020; Das et al., 2018; Mottaleb \& Sonobe, 2011) found low productivity, poor infrastructure, low research \& development, non-availability of spinning 
facilities, and diseconomies of scale as drawbacks that led to poor performance of the Bangladeshi RMG industry. For example, the country witnessed a $1.2 \%$ negative growth rate in the global garment export share in 2019, while India and Pakistan enjoyed a positive growth rate of $2.2 \%$ and $4.74 \%$, respectively, during the same period (Islam, 2021; Rahman, 2021; Zaman, 2021). Neighboring competitive countries seem to be taking advantage of the global market share more effectively than Bangladesh.

Although many studies have looked into Bangladesh's competitive advantage in the RMG industry, little research has examined its garment exporter's internal strategies or resources that could be used to compete more effectively in the global marketplace. Previous studies (Yunus \& Yamagata, 2012; Kathuria, 2013; Alam et al., 2017; Mostafa \& Klepper, 2018; Hossian et al. 2019; Rasel et al. 2020; Hasan et al., 2020; Islam, 2021; Zaman, 2021; Bari \& Jin, 2021) found a vast labor force, low wages, suitable locations, and export-friendly policies as the competitive advantages of Bangladesh's RMG industry. These studies (Yunus \& Yamagata, 2012; Alam et al., 2017; Mostafa \& Klepper, 2018; Chandra \& Ferdaus, 2020; Islam, 2021; Bhuyan \& Oh, 2021) were focused primarily on the post-Multi-Fiber Arrangement (MFA) quota period (2005-2015) and used secondary data to identify the competitive advantages. However, no recent study has been conducted to determine the present competitive advantages of the Bangladeshi ready-made garments industry from the executive's perspective who are the life of this industry.

To address the shortage of research on the present competitive advantage situation, the current study has two main objectives: (1) to identify resources that are helping the Bangladeshi RMG exporters to gain and sustain competitive advantage in the global market according to the executives working there and (2) to understand the impact of government and chance factor in the Bangladeshi RMG exporters key resources.

To achieve these research objectives, a qualitative research design using in-depth semi-structured interviews with RMG executives in Bangladesh was carried out. The findings provide an original contribution to studies on the current competitive advantages of Bangladesh's RMG which have been researched to a limited extent but only from a secondary data perspective.

\section{Literature Review}

\section{RMG Industry of Bangladesh}

The RMG industry of Bangladesh is considered one of the fastest-growing industries after the 1990s (Alam et al., 2017; Zaman, 2021). We can track the Bangladesh garment export industry's history following the independence of Bangladesh in 1971. In the 1970s, the RMG trade was a micro-business enterprise that fulfilled domestic demands and was dominated by small tailoring outfits (Rasel et al., 2020). Tailoring was a popular business operated by skilled master tailors who could cut and sew cloth according to customers' measurements and fittings. One such tailoring enterprise, Reaz garments, started manufacturing woven shirts in large quantities for export. The company exported Bangladesh's first order of 10,000 woven shirts to France in 1978 (Yunus \& Yamagata, 2012; Zaman, 2021).

Multi-Fiber Arrangement (MFA) offered Bangladesh a quota-free status which attracted foreign investors. This led to the establishment of several joint ventures or foreign privately owned garment manufacturing facilities in the early 1980s (Alam et al., 2017; Akter, 2020; Zaman, 2021). Bangladesh was brought under the MFA quota system in 1986, and this opened the doors for Bangladesh to new markets such as the USA (Ahmed, 2009; Akter, 2020; Mottaleb \& Sonobe, 2011). In 2005, after almost 19 years, the MFA quota system was terminated. Before it was terminated, RMG exports from Bangladesh grew at an annual average rate of $19 \%$ between 1990 and 2005 (Alam et al., 2017; Akter, 2020). After the abolition of the quota system, from 2005 to 2019, the average growth rate was 21\% (Export Promotion Bureau, 2019). Additionally, the Generalized System of Preference (GSP) allowed Bangladesh to export RMG products to the European Union (EU) without any tariff, while the tariff rate on RMG products was $12.5 \%$ for all other countries (Bhattacharya \& Rahman, 2000; Hasan et al., 2020; Islam, 2021).

\section{RMG Product and Export Region}

The RMG products of Bangladesh are mainly categorized into Woven and Knit. In 1992, woven export accounted for $86 \%$ of total garments export and knitwear export accounted for only 14\% (Alam et al., 2017; BGMEA, 2021a, 2021b). However, the current scenario has dramatically changed, with woven exports accounting for $51 \%$ and knitwear exports accounting for 49\% (Akter, 2020; BGMEA, 2021a, 2021b). The major reason for the decline of woven export is the dependence on imported raw materials which caused a delay in production and impacted delivery time. On the other hand, domestically produced yarn and fabrics are used for knitwear production which speeds up the production process (Bhuyan \& Oh, 2021; Chandra \& Ferdaus, 2020; Mottaleb $\&$ Sonobe, 2011).

The RMG industry of Bangladesh exports a variety of RMG items for men, women, and kids, such as shirts, jackets, trousers, sweaters, t-shirts, etc. Among them, T-shirts (USD 5.6 billion) and trousers (USD 5.4 billion) have the highest export value (BGMEA, 2021a, 2021b). Bangladesh's RMG is concentrated mainly in two markets: the European Union (EU) and the United States of America (USA). These 
two markets comprise approximately $83 \%$ of Bangladesh's total RMG export in 2020 (BGMEA, 2021a, 2021b; Islam, 2021). The RMG industry's exports to the EU were valued at 17.02 billion USD in 2020 which was the highest followed by the USA valued at 5.06 billion USD and Canada valued at 0.8 billion USD (BGMEA, 2021a, 2021b).

\section{Competitive Advantages of the Bangladeshi RMG Industry}

Over the last 15 years, the RMG industry has revolutionized the country in terms of its contribution to GDP, employment for rural people, women empowerment, and socio-economic developments (Hasan et al., 2020; Mostafa \& Klepper, 2018; Zaman, 2021). In 2020, Bangladesh contributed 6.4\% toward the global RMG market share (Akter, 2020; Chandra \& Ferdaus, 2020). This number is greater than some competitor countries like Vietnam (6.2\%), India (3.3\%), and Turkey (3.1\%) (Hasan et al., 2020; Islam, 2021). The huge volume of garment exports helped the RMG industry to grow at a constant rate every year.

The number of RMG firms in Bangladesh has increased over time, and currently, a total of 4,406 firms produces garment items for export purposes in Bangladesh (BGMEA, 2021a, 2021b). Low labor cost is considered as one of the primary reasons for the growth of the RMG industry in Bangladesh (Mostafa \& Klepper, 2018; Rasel et al., 2020). However, low labor productivity has been an issue for the Bangladeshi RMG industry. Labor productivity in Bangladesh was found to be the lowest among the other apparel manufacturing nations such as Cambodia, Vietnam, Pakistan, India, and China (Akter, 2020).

The size of the RMG manufacturing firms of Bangladesh also provides a competitive advantage for the country as large manufacturing firms usually have more capital and human resources (Chandra \& Ferdaus, 2020; Hasan et al., 2020; Momaya, 2001). They also have a higher capacity to absorb the risk than smaller firms (Agrawal et al., 2021; Bair et al., 2020). The average size of a Bangladeshi firm is 797 employees per firm, which is much higher than some competitor countries like Vietnam (426 employees per firm) and China (269 employees per firm) (Alam et al., 2017). Additionally, a suitable location (Dhaka, Chittagong) of Bangladesh's RMG firms helps achieve better export performance (Akter, 2020; Islam, 2021).

The government of Bangladesh has also taken many steps to enhance the economy through liberalization policies and reforms that brought in foreign investment in the RMG manufacturing industry (Hossian et al., 2019; Rasel et al., 2020; Hasan et al., 2020). A bonded warehouse is one of the facilities that has been provided by the Bangladeshi government on which RMG firms can import raw materials without paying any import duty (Ahmed, 2009; Akter,
2020). The government of Bangladesh also established the Export Processing Zone (EPZ) to help the RMG manufacturing industries to grow (Rahman, 2021).

Additionally, product diversification and export market diversification helped Bangladesh to become a powerhouse in RMG export. The availability of domestically produced raw materials for knitwear has boosted the knitwear exports for Bangladesh, whereas the export firms have to rely on imports for manufacturing woven products (Mottaleb \& Sonobe, 2011; Hossian et al., 2019; Rahman, 2021; Lavassani \& Movahedi, 2021).

Although Bangladesh improved its competitive advantages, the RMG industry is still plagued by factory fires, building collapses, and labor rights violations. The collapse of the Rana Plaza factory building killed 1133 people (Mostafa \& Klepper, 2018; Rasel et al., 2020; Hasan et al., 2020). Thousands of factory workers were also critically injured by this incident. After that incident, the European and American retailers established the Accord and Alliance (Ahlquist \& Mosley, 2021; Liu et al., 2019). The Accord primarily works to make the RMG factory a safe place for the workers. They work with both the brands and trade unions to make their vision come true (Ahlquist \& Mosley, 2021). The Alliance was also created as a collaborative initiative to improve the safety condition of the RMG industry of Bangladesh.

\section{Conceptual Framework: Porter Diamond Theory of National Competitive Advantage}

The Porter's Diamond Model is considered a strategic economic model and explains how or why one country or nation is more competitive in a particular industry than another nation (Liu, 2021; Porter, 1990; Wang \& Li, 2020). In this model, Porter (1990) described how a specific firm's competitiveness is related to the performance of other firms in a similar industry. He also stated that an industry or firm always tries to improve and develop its performance to gain competitiveness (Momaya, 2019; Alavi et al., 2020). The target is to gain and sustain these advantages in the international market. Policymakers, marketers, and governments use this model to design a long-term development plan for their nation and achieve a competitive advantage (Jin \& Moon, 2006; Halife, 2020; Alavi et al., 2020; Liu, 2021). Porter (1990) found four primary determinants that affect firms' competitive performance, including (1) factor conditions, (2) demand conditions, (3) related and supporting industries, and (4) firm strategy, structure, and rivalry. The determinants interact with each other to develop national competitiveness for any particular industry (Liu, 2021; Wang \& Li, 2020). The government and the chance factor also influence the four determinants as it has the power to 
impact the process of development of a nation's competitive advantage.

\section{Factor Conditions}

Factor conditions can be defined as a nation's position in production constituents, such as labor, infrastructure, and resources necessary to compete in a given industry (Alavi et al., 2020; Liu, 2021). Porter (1990) identified factor conditions as human resources, physical resources, knowledge resources, capital resources, and infrastructure. He further subdivided the factor conditions into primary and advanced factors. Primary factors include climate, location, available materials, natural resources, unskilled labor which does not require further investment. Advanced factors include skilled labor, digital data, communications, and infrastructure which can be upgraded through reinvestment and innovation.

From the Bangladeshi RMG manufacturing firm's perspective, cheap labor, location, and favorable climate can be considered as the primary factor conditions and communication, and infrastructure as advanced factor conditions (Hasan et al., 2020; Mostafa \& Klepper, 2018; Rahman, 2021; Uddin, 2014; Yunus \& Yamagata, 2012).

\section{Demand Conditions}

Porter (1990) described demand conditions as the size and nature of the home market demand for the industry's product or service. If the scope of a home market is large, firms will become more competitive and financially stable (Liu, 2021; Wang \& Li, 2020). Porter (1990) suggested four aspects of demand conditions: home demand composition, demand size and pattern of growth, internationalization of domestic demand, and the interplay of demand conditions.

The demand for domestic apparel in Bangladesh is much lower compared to international demand. This lower demand lessens the competitiveness within the apparel firms. Additionally, the future of domestic apparel demand in Bangladesh has also deteriorated as the international demand is increasing constantly and the apparel firms are more focused on fulfilling the international demand (Rahman \& Anwar, 2007; Islam, 2021; Zaman, 2021).

\section{Related and Supporting Industries}

Related and supporting industries can be defined as the availability of supplier industry or any other related industry in the market, which assist any specific industry to grow more and become more competitive (Liu, 2021; Tsai et al., 2021). It is an important determinant because the presence of related industries creates pressure for that specific firm or industry to compete nationally and internationally. Additionally, supporting industries that are highly competitive in the global market can provide cost-effective and efficient input for that firm or industry.

The related and supporting industries in the RMG industry of Bangladesh can be described as the textile raw materials industry, subcontractors, logistics, and financial institutions (Akter, 2020; Islam, 2021). The banks and insurance companies are the other two main supporting industries that assist the RMG industry by providing working capital to fulfill its contractual terms (Bhuyan \& Oh, 2021; Uddin, 2014). However, the garment industry of Bangladesh didn't get enough support from the local textile raw materials industry as the demand always remains higher than the supply. So, the garment industry had to import most of their raw materials such as yarn, zippers, buttons, and labels from other countries which increase the production lead time and product price (Islam, 2021).

\section{Firm Strategy, Structure, and Rivalry}

Porter (1990) described firm strategy, structure, and rivalry as conditions in the nation governing how the companies are created, organized, and managed as well as the nature of the domestic rivalry. Firm structure, strategy, and rivalry mainly depend on that nation's culture, such as how people contribute towards their nation, how they interact with each other, and how they behave within an organization (Halife, 2020; Tsai et al., 2021). Additionally, higher rivalry makes an industry attractive in the international market.

The RMG industry of Bangladesh has gradually developed its firm structure and strategy over the last two decades. Most of the RMG firms are inspected and certified by Accord on Fire and Building Safety certification established by European retailers after the building collapse tragedy in 2013 (Ahlquist \& Mosley, 2021; Liu et al., 2019). The RMG firms now also have better transportation facilities that speed up the delivery process (Islam, 2021).

\section{The Role of Government}

Porter (1990) stated that government plays an influential role in the nation's competitiveness. The role of the government is mainly to assist the firms or industry to innovate and help them become more successful in the global market (Alavi et al., 2020). Porter (1990) stated that it is the firms or industry which creates competitive advantages for themselves. The government can only influence or push those firms to be competitive through favorable policies and financial help.

Bangladesh's government implemented several policies that helped in the growth of the RMG industry during its early stages. A back-to-back letter of credit (L/C) which provides a financial security or guarantee from the Bangladeshi government-owned bank for the international material supplier for any kind of failure of payment was one of those 
policies that helped RMG firms to grow (Alam et al., 2017; Islam, 2021). Import tariff exemptions and free warehouse facilities are also some of the major steps that have been taken by the government of Bangladesh (Zaman, 2021).

\section{Chance}

Porter (1990) defined chances as the event that cannot be controlled by the firm or industry authority. Moreover, chances are unexpected events on those there is little or no control. Chances could be a natural disaster, political riots, financial markets or exchange rates, military war, or any sudden situation that hamper the competitive advantages of that firm or industry (Liu, 2021).

The RMG industry of Bangladesh has been affected by various chance factors. Labor unrest, factory building collapse, and factory fires are the most common chance factors affecting the Bangladesh apparel business (Akter, 2020; Das et al., 2018; Uddin, 2014). The COVID-19 pandemic also has a harsher impact on the RMG industry of Bangladesh. The pandemic caused the temporary closure of RMG manufacturing firms due to mandatory lockdown orders from the government, downward demand shifts, and safety and health issues. Many firms had to close their business operations permanently as they did not have enough financial backups to restart their firms.

\section{Methodology}

This study aims to gain an in-depth understanding of the firm resources that the Bangladeshi RMG industry has. Additionally, the study also investigates how various factors such as ownership, government policies, nation's environment, and financial agreements affect the resources of the RMG industry, which helped them gain a competitive advantage. A qualitative interview was employed to identify the original resources that the RMG firms of Bangladesh have (Evans \& Lewis, 2018). A qualitative interview was used because qualitative inquiry helps to better understand a topic of which little is known (Creswell, 2014; McGrath et al., 2019).

As this study is exploratory, semi-structured interviews were employed as a suitable research design (Evans \& Lewis, 2018). A semi-structured interview allows for an open-ended response from the interviewee to get more indepth information and encourage two-way communication (McGrath et al., 2019). Table 1 provides a sample of questions that were asked in the interviews.

\section{Sample}

A participant list was developed in the following ways to locate a group of participants representing Bangladesh's RMG industry: (a) through a business directory, and (b) through personal contacts. Upon approval of the university Institutional Review Board, participants were recruited. In total 68 participants were selected for this study who represented the management of their organization. Participants were then contacted by email. Study details and IRB approval forms were also provided. Out of the 68 emails sent, 23 participants responded to the emails. However, saturation was met with 14 interviews, as additional interviews yielded no new information (Francis et al., 2010; McGrath et al., 2019). International phone interviews were arranged with the selected participants between March 2020 and August 2020. Table 2 presents descriptions of the study participants.

\section{Data Collection and Analysis}

Semi-structured interviews allowed for supplementary questions and dialouge (Evans \& Lewis, 2018). The length of the interviews lasted from 30 to $60 \mathrm{~min}$. First author conducted all the interviews with the managers and executives of the Bangladeshi RMG industry. All the interviews conducted were recorded with the consent of the interviewees and the audio recordings were transcribed accordingly.

All subjects and materials of the interview process were coded without any personal identifiers. Each interview transcript was reviewed and coded by the individual researcher. Researchers used an open coding process which assisted them in identifying the recurring codes (Parameswaran et al., 2019; Tavory, 2020). After every interview, researchers also wrote the analytic memos to identify the connections between the codes (Saldana, 2016; Tavory, 2020). Memoing helped to get or understand any predetermined meanings from the data (Evans \& Lewis, 2018). Intercoder Reliability was found to be 92.37 percent which is higher than the recommended threshold (Creswell, 2014; Saldana, 2016; Parameswaran et al., 2019).

The data obtained after the transcribing and coding process were then interpreted by emerging themes (Tavory, 2020). A comprehensive analysis of the words in each transcript was conducted, followed by a comparison of themes and patterns across the transcripts. The data were broken up and arranged into themes continuously until the patterns, and corresponding categories emerged (Evans \& Lewis, 2018). The researcher's reflexivity and participant feedback were the validation strategies used to ensure the themes' validity 
Table 1 Interview questions sample

\begin{tabular}{|c|c|}
\hline Segments & Sample questions \\
\hline Demographic segment & $\begin{array}{l}\text { How long have you been with this company? } \\
\text { Please describe your current title and years in this position }\end{array}$ \\
\hline Key resource segment & $\begin{array}{l}\text { What are your company's unique strengths that a competitor would find it hard to imitate? } \\
\text { How was your company able to obtain or build those strengths? } \\
\text { What do you do to be different from your competitors? } \\
\text { What is present condition of the natural resources of Bangladesh that help the RMG industries to grow, } \\
\text { (specially your industry)? } \\
\text { How is the present working condition (labor safety, working hour, compliances, working environment) } \\
\text { of your company? }\end{array}$ \\
\hline Ownership segment & $\begin{array}{l}\text { How and when was your company founded? } \\
\text { Is it a joint venture, foreign, or domestic ownership? } \\
\text { What are the strong points your organization has because of this "domestic/non-domestic" ownership? } \\
\text { What are the negative points your organization has because of this "domestic/non-domestic" ownership? }\end{array}$ \\
\hline Demand condition segment & $\begin{array}{l}\text { Who is your main buyer for your products (Buyers)? } \\
\text { What makes your company favorable to do business with them? } \\
\text { What are the major demands of your buyers from your organization? }\end{array}$ \\
\hline Supporting industry segment & $\begin{array}{l}\text { What are the related industries other than the apparel affects your businesses the most? } \\
\text { How those industries help or deter your business? }\end{array}$ \\
\hline Government support segment & $\begin{array}{l}\text { What are your views of the government export support schemes? } \\
\text { What are the benefits of these government support schemes? }\end{array}$ \\
\hline Chance segment & $\begin{array}{l}\text { Are there any events or occurrences happened in your firm that affect your organization? } \\
\text { Are there any events or occurrences outside of the apparel export industry that affect your organization? }\end{array}$ \\
\hline General segment & $\begin{array}{l}\text { In your opinion where do you see the Bangladesh's apparel industry in future? } \\
\text { Are there any thoughts or opinions you would like to share? }\end{array}$ \\
\hline
\end{tabular}

Table 2 Basic demographic description of interview participants

\begin{tabular}{lllllll}
\hline Participant name & Designation & Company name & $\begin{array}{l}\text { Years of } \\
\text { employment }\end{array}$ & Product category & Ownership type & Major buyer \\
\hline Bikas & Merchandiser & ABC Apparel & 4.5 year & Knit & Domestic & Europe and USA \\
Shaan & Senior Merchandiser & BCD Group & 5 year & Knit and Woven & Foreign & Europe and USA \\
Suvo & Senior Executive & CDE Fashion & 4.5 year & Knit and Woven & Foreign & Europe \\
Rup & Assistant Manager & DEF International & 6 year & Woven & Domestic & Europe and USA \\
Nish & Merchandiser & EFG Apparel & 4 year & Knit & Domestic & Europe \\
Palash & Merchandiser & FGH Fashion & 7 year & Knit & Domestic & Europe \\
Mihir & Senior Merchandiser & GHI Group & 6 year & Knit and Woven & Joint Venture & Europe and USA \\
Som & Senior Executive & HIJ Textiles & 5 year & Woven & Domestic & Europe and USA \\
Avi & Merchandiser & IJK Apparel & 4.5 year & Woven & Domestic & Europe and USA \\
Nafisa & Senior Officer & KLM Group & 5 year & Knit and Woven & Domestic & Europe and USA \\
Rahman & Merchandiser & LMN Holding & 4.5 year & Knit & Domestic & Europe and USA \\
Anwar & Senior Executive & MNO Group & 5 year & Knit and Woven & Domestic & Europe and USA \\
Fahid & Merchandiser & NOP Garments & 5 year & Knit and Woven & Joint Venture & Europe and USA \\
Monir & Merchandiser & OPQ Textiles & 5.5 year & Knit and Woven & Joint Venture & Europe and USA \\
\hline & & & & & &
\end{tabular}


(McGrath et al., 2019). The themes obtained from the interviews were sent to all of the participants for their feedback and 8 of the participants responded and their feedback was positive.

\section{Results}

\section{Key Competitive Advantages}

Participants described four key competitive advantages that they have over their competitors: (a) price advantage attained through aggressive product pricing, (b) on-time delivery advantage through speedy transport infrastructures, (c) quality advantage through the skilled workforce, and (d) product advantages that the Bangladesh firms acquired through competitive price and product variety.

\section{Price Advantage}

Price advantage emerged as the most critical competitive advantage. Twelve participants described the capacity to provide products at market prices as a competitive advantage. To the participants, price advantage did not necessarily mean the lowest price. Out of the fourteen participants, three stressed the importance of maintaining a "competitive price" to sustain their business. Avi and Nafisa, both merchandisers, working at an export firm, described the apparel business of Bangladesh by expressing his belief that it is controlled by "affordable and competitive" product price.

Avi: "Production delays are a strict no-no in today's cut-throat garment export business. The margins have reduced, and the lead times have shortened. To sustain our business, price is critical, or else we lose orders to Vietnam and China".

Nafisa: "We are always conscious about our pricing and try to maintain a competitive price for all of our products".

\section{On-Time Delivery Advantage}

The ability to deliver products on time emerged as the second important recurring theme. Developing the physical infrastructure and upgrading the machinery seemed to be essential resources for achieving an on-time delivery advantage. Eleven participants stated transportation infrastructure as a critical firm resource. Previous research (Yunus \& Yamagata, 2012; Alam et al., 2017) pointed out the lack of proper infrastructure for global competition in the Bangladeshi RMG industry. However, in this study, it was interesting to see that the participants emphasized the infrastructure developments.
The Bangladeshi RMG firm's investment in transportation infrastructure and efforts to increase productivity is a relatively new phenomenon. Three participants mentioned that they are in their initial phases of implementing these efforts. Seven participants described "transportation, shipping, and cargo services" and four participants described "government policies in improving transport facilities" as the infrastructural development activities that help Bangladeshi firms attain on-time deliveries. Bikas, a merchandiser of an apparel export firm, cited "shipping company" and "government schemes" as crucial resources to deliver products on time regularly:

Bikas: "Government export schemes are very helpful. These schemes reduce the lead time in production and help us to deliver the product on time".

Anwar: "Timely delivery is very important for us as we want to sustain a good relationship with our buyer".

\section{Quality Advantage}

The ability to provide products of a better quality was found to be another essential competitive advantage. Eight out of fourteen participants described "ensuring quality" as a key competitive advantage. Two participants also stressed the importance of having "skilled workers" to maintain good quality to attain competitive advantage. Five of the study participants shared that a quality product is a product that would satisfy buyers so that the participants do not have to repeat production. "No compromise on quality" was found to be an important trend among the participants. Som, a senior executive in an apparel export firm, stated that having a robust technical team was essential in maintaining product fit, product variety, and upholding the quality standard requirements. It seemed that quality is an essential component for developing a good relationship with the buyer.

Som: "For us, better product quality is of utmost importance as we are working with quality and not quantity. We cannot afford to lose buyers in today's economy".

Rahman: "We ensure quality and commitment. We have a high profile technical and quality team to improve the lean manufacturing process".

\section{Product Advantage}

Six participants described the ability to provide variety in their product at a reasonable price as one of their key competitive advantages. The ability to produce in "huge" or "large" quantities also seemed to be aiding the export firm's product advantage. Three participants described the ability to manufacture in large quantities as a key resource. "Training programs" and "the sharing of technical knowledge" 
between buyers and firm managers also were found to be consistent key resources that helped the firms attain product advantage.

Rup: "Foreign buyers share their knowledge and experience about the latest production system and any specialized fabric. That helps us to develop our skills".

\section{Porter's Determinants:}

\section{Factor Conditions to Build Competitive Advantages}

The managers described the unique factor conditions of the Bangladeshi RMG export firms as (a) Accord and Alliance certification, and (b) human resources.

Almost all participants described certifications by Accord and Alliance as a factor condition. This was not surprising, as the Bangladeshi RMG industry has faced many accidents due to poor physical infrastructure, the most consequential incidents being the Rana Plaza building collapse and the Tazreen factory fire. The above certifications seemed to authenticate the firm's claim of having a strong infrastructure and were used as a tool to attract buyers.

Shaan: "Accord engineers have physically verified all the items based on the standards developed by the Bangladesh Government, Accord \& ILO”.

Human resources emerged as the next most frequently described factor condition to develop and maintain a competitive advantage. Seven participants described employees, skilled operators, and workers as key human resource management factors for their organization. This was consistent with Zaman (2021) who found skilled workers and laborers to be an essential resource for the growth of Bangladesh's RMG industry.

A good work environment and better working relationships emerged as important human resource development processes. The managers described providing a good work environment as a retention tool as it created positive energy for the internal growth of their employees. They also emphasized the importance of having a "better relationship" with workers. It may be deduced that a better relationship with workers can lead to higher productivity.

Som: "The owner keeps a good relationship with the workers and officers and motivates everyone. That's why it is helpful for us to work in this company".

\section{Demand Conditions to Build Competitive Advantages}

Quality, infrastructure, good customer relationships, labor welfare, and productivity were found to be the critical factors influenced by demand conditions. Out of the fourteen firms analyzed, three firms exclusively exported to the EU and eleven firms exported to both the USA and EU. The key factors found to be influenced by the EU's demand conditions were: (a) quality and (b) good relationship; and by the USA's demand conditions: (a) infrastructure and (b) labor welfare and productivity.

RMG firms working with EU buyers focused both on quality and quantity as the EU buyers give a large number of orders and do not compromise on quality. Also, the firms need to put a competitive price tag for EU buyers to maintain a strong relationship that will bring more orders for the firms. It was also found that all fourteen export firms preferred working with EU buyers as they felt more confident in communicating with the EU buyers than other buyers. On the other hand, buyers from the USA focus more on the firm's infrastructure and labor conditions. After the Rana Plaza incident, US buyers have been more stringent on their requirements. They also stress quality products along with quantity.

Avi: "We provide quality products and on-time shipment. The buyers arrange training programs and share technical knowledge with us that helps us in maintaining buyer's quality standards".

\section{Supporting Industries that Help Build Competitive Advantages}

Textile raw materials industry, shipping services, transportation and cargo services, spinning and dyeing industries emerged as the key supporting industries that influenced the competitive advantage of Bangladeshi RMG firms. Nine out of the fourteen participants named shipping, transportation, and cargo services as the main supporting industries. Competitive pricing and a well-established relationship with suppliers were found to be the vital competitive resources obtained through their supporting industries. In this study, Som described how transportation companies affected product pricing and could "make or break" an order while stressing the importance of the transportation companies. Porter (1990) stated that domestic firms in related industries often build a formal alliance and shared activities, which has happened in Bangladesh's RMG industry.

However, participants also shared that Bangladesh needs to source textile raw materials from outside the country due to lack of local supply. Bangladesh imports most of their yarns, woven fabrics, dyeing chemicals, garment accessories, and packaging materials from China which leads to the higher product price and thereby negatively affects the competitive price advantage. 


\section{Firm Ownership Type to Help Build Competitive Advantages}

Firm ownership types that emerged from the study were domestic-owned firms, joint venture firms, and foreignowned firms. The majority of the participants (nine out of fourteen) belonged to domestic ownership firms. (a) Ontime delivery, (b) quality assurance, and (c) human resources were the key resources influenced by domestic ownership. However, foreign-owned firms (two out of fourteen) seemed to emphasize (a) marketing strategies, (b) quality standards, and (c) product pricing.

It was intriguing to observe that most (seven out of nine) participants believed that domestic ownership helped them maintain a good relationship with both the buyer and worker. Participants also described foreign ownership as a boon as "foreign owner has networking links with a lot of buyers" and brings business to factories. However, the participants described foreign ownership as having "less communication with workers" and "higher factory overhead cost."

Quality was found to be a shared resource across firm ownership. Five participants described quality structure, product quality, and quality enforcement as essential resources of their organization. The participants believed that they received constant orders from the buyers because of their product quality. Maintaining the quality standards across product lines seemed to be a common theme among Bangladeshi RMG export firms. Three participants described "a consistent quality level" as a key tool in ensuring uniform product quality. Interestingly, the participants focused on the long-term benefits and did not want to compromise quality for short-term profits.

Palash: "We never compromise our quality. Having a good quality is responsible for the reputation of our company".

\section{Government Policies that Promote Competitive Advantages}

The central government policies that influenced the competitive advantages of Bangladeshi RMG export firms were export subsidies, export processing zones (EPZ), and financial services. It was interesting to note that all fourteen participants described the government's EPZs and subsidies as a success. Twelve-of-the-fourteen participants identified these government policies as having long-term goals and objectives, positively impacting these firms' competitive advantages.

The establishment of EPZs encouraged investors to construct RMG export firms. The EPZs were successful in attracting foreign investors to set up their RMG export firms. Six participants stated that the facilities provided under the EPZs have helped their companies be more competitive globally. Shaan stated that the EPZs provided the necessary infrastructure including proper transportation and electricity.

Nish: "Government export schemes have been very helpful. There are enough EPZs and these have helped the apparel business in Bangladesh".

Access to international banking and financial services was found to be another government support that was helping Bangladeshi RMG firms. Easy access to banking facilities for the apparel firms and business loans with low-interest rates also were found as key resources helping Bangladeshi RMG firms to gain a competitive advantage. Alam et al. (2017) also found banking facilities as a major contributor to progress in the RMG industry of Bangladesh.

Som: "Government has a very positive approach to increase the business volumes by giving loans to the industry with a lower rate of interest and providing international banking facilities".

\section{Chances}

COVID-19 was found to be the leading chance factor influencing the competitive advantages of Bangladeshi RMG export firms at the point of the interviews. Nine out of the fourteen participants cited the novel coronavirus as a chance factor affecting them. They also reported that the COVID19 pandemic has drastically affected their key resources. The COVID-19 pandemic seems to be assisting the firms to reduce wastages widespread in the Bangladeshi RMG export industry. Most firms had to reduce their overhead costs, which has prompted them to figure out ways to improve their productivity due to the pandemic.

Avi: "The COVID-19 virus has affected our production. We cannot source fabric from China. Many of our production lines are stopped".

Though COVID-19 slowed down businesses, it brought the inefficiencies of the Bangladeshi RMG export industry into the open. The pandemic also exhibited Bangladesh's reliance on foreign raw materials. Due to COVID-19, the import of raw materials from foreign countries had to be halted, which greatly impacted factory production lines. Most of them do not have the fabrics they need to produce apparel for exports. The overall findings of this study is illustrated below (Fig. 1). 


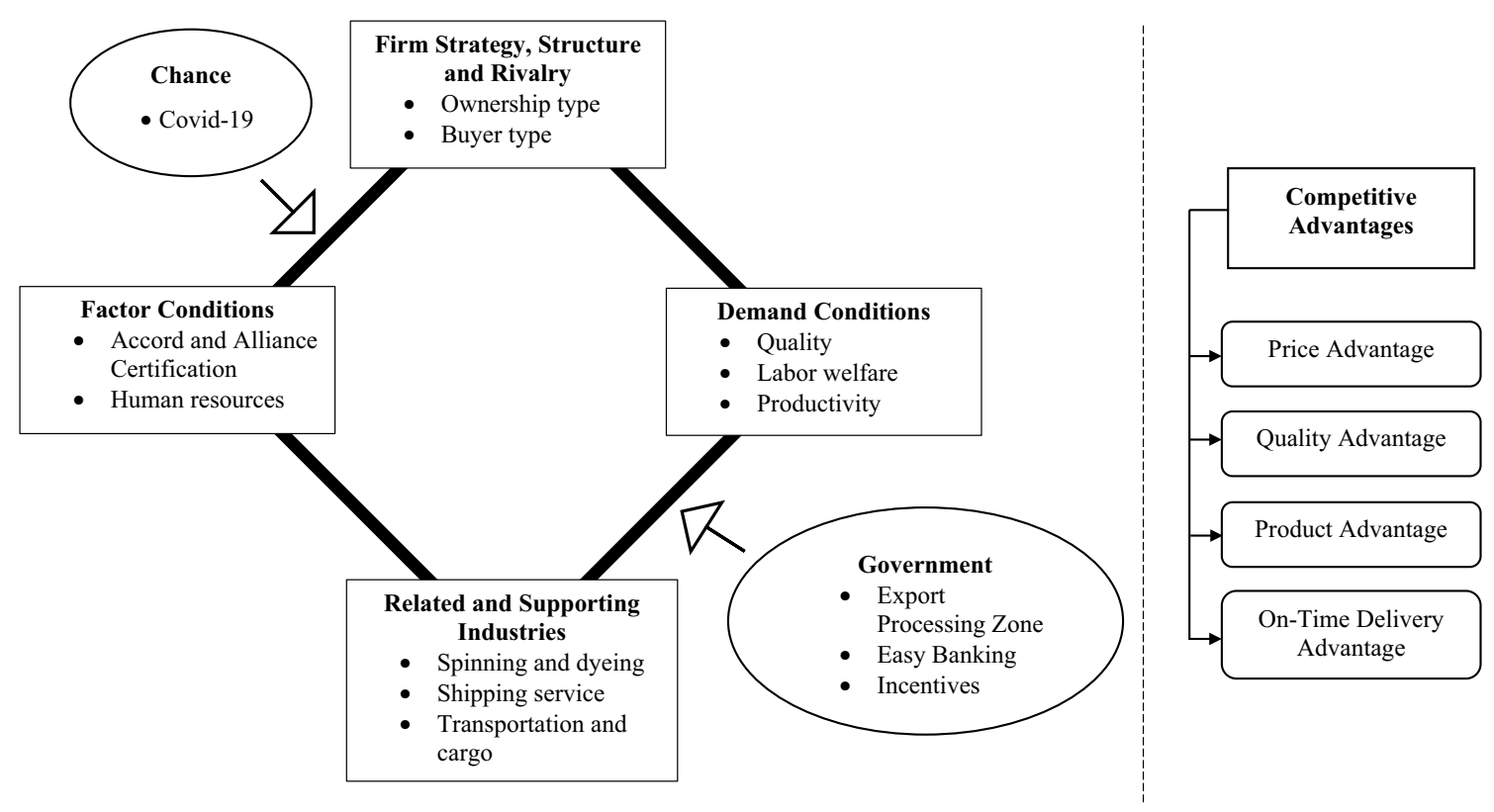

Fig. 1 Bangladesh's competitive advantages. Adapted from Porter (1990) model

\section{Discussion and Conclusion}

The RMG industry has contributed vastly to the economic development of Bangladesh, a small South Asian country that now has moved from low-to-middle-income status. After the abolition of the quota system, 2005 to the 2022, the average growth rate of the RMG export business in Bangladesh is $21 \%$. This is higher than some other competitor neighbouring countries (India, Pakistan). The RMG industry is now contributing about $20 \%$ of the country's GDP. Additionally, the RMG industry currently employs around 5 million people, and about $80 \%$ of the workers are women, thereby making the country's women more empowered than before.

The results of this study revealed exciting findings of the RMG industry of Bangladesh. First, competitive price is considered as the most important resource by the RMG exporting firms in Bangladesh, followed by on-time delivery and quality. Second, most RMG firms of Bangladesh seemed to have good infrastructure, indicating that they can produce large quantities of orders and can deliver on time, thus attracting foreign buyers to Bangladesh. Third, ownership type and buyer type have a significant influence on the major resources of the Bangladeshi RMG firms as it was found to impact the firms' physical and organizational resources positively. Lastly, government policies have had a positive impact on the RMG export business of Bangladesh as it has provided exporting firms with several facilities that have helped the firms to grow and prosper.
The study results have provided major implications and contributions. First, the study findings provide a clear picture of the major resources of the Bangladeshi RMG export industry, which contribute towards competitive advantages. The findings also provide information about the factors that affect the competitive advantages of the RMG industry. Second, the findings of this research on major resources might assist the RMG industry of Bangladeshi in developing and sustaining those resources to achieve a competitive advantage. Third, the study findings may help both domestic and foreign investors who are planning to invest in the RMG export business of Bangladesh. Both local and foreign investors who planned to invest in the RMG industry of Bangladesh need to develop the major resources before investing. Fourth, policymakers also may find the study results very useful. Participants in this study described some government policies such as setting up EPZs and tax reduction as very useful to assist them in being more successful. Participants also described some governmental work activities like longwork processing time, complex work procedures that negatively affect their business. Policymakers might need to develop new export-friendly policies and improve the existing ones for the rapid growth of this RMG industry. Finally, the findings of this study might help the apparel or garment-related educational programs in Bangladesh. Adding the study findings to the existing curriculum may help students gain a deeper understanding of the competitive advantages of Bangladesh's RMG export industry so they can help the RMG export industry in the future to achieve unique key firm resources. The study findings 
support and expand Porter's (1990) theory as we used the model to understand the competitive advantages of the RMG firms in Bangladesh. Also, it helped in understanding the different factors influencing the Bangladeshi RMG firm's key resources.

The study has certain limitations. It was conducted based on qualitative interviews of fourteen top-level management personnel in selected RMG firms of Bangladesh. It was not possible to collect data from all types of RMG firms in Bangladesh. Additionally, phone interviews have certain limitations such as the researcher not being able to observe the non-verbal responses of the participants. Further quantitative studies involving survey method with a large number of participants across different geographical areas are needed to generalize the results. Future research is also recommended to better understand the effect of supporting industries and chance on the export competitiveness of the Bangladeshi RMG export industries.

\section{Key Questions Reflecting Applicability in Real Life}

1) How present competitive advantages in the RMG industry making Bangladesh a manufacturing hub?

2) Which resources of the RMG industry can help with rapid recovery from COVID-19 pandemic?

3) Which factors are mostly affecting the Bangladeshi RMG production?

4) What role the government of Bangladesh playing in the development of the RMG export industry?

5) How can Bangladesh be the next China in RMG export?

Acknowledgements The first author (ISS) would also like to express sincere thanks to the Department of Fashion Dress and Merchandising of the West Virginia University for accepting him as a graduate student, supporting him to conduct research, attend classes, seminars and conferences, and giving him a rare experience. Authors would like to thank the reviewers of the JGBC editorial team and Dr. Kirankumar Momaya for their kind suggestions and support.

Author Contributions First author (ISS) collected, analyzed and interpreted the data regarding the competitive advantage, history and growth of Bangladeshi apparel industry, and drafted the manuscript. Second author (DD) conceived and designed the study and revised the manuscript critically for important intellectual content. Both authors read and approved the final manuscript.

Funding Not applicable.

Availability of Data and Materials The data supporting the findings of this study are available on request.

\section{Declarations}

Conflict of Interest The authors declare there is no conflict of interests.

\section{References}

Agrawal, S., Singh, P., \& Mazumdar, M. (2021). Innovation, firm size and ownership: a study of firm transition in India. International Journal of Global Business and Competitiveness, 16(1), 15-27. https://doi.org/10.1007/s42943-021-00022-y

Ahlquist, J. S., \& Mosley, L. (2021). Firm participation in voluntary regulatory initiatives: the Accord, Alliance, and US garment importers from Bangladesh. The Review of International Organizations, 16(2), 317-343. https://doi.org/10.1007/ s11558-020-09376-z

Ahmed, N. (2009). Sustaining ready-made garment exports from Bangladesh. Journal of Contemporary Asia, 39(4), 597-618. https:// doi.org/10.1080/00472330903076891

Akter, P. (2020). An overview of the ready-made garment (RMG) sector of Bangladesh: from origin to the current state of pinnacle. Kyushu University Graduate School of Economics. https://doi.org/ $10.15017 / 4067129$

Alam, M., Selvanathan, E., \& Selvanathan, S. (2017). Determinants of the Bangladesh garment exports in the post-MFA environment. Journal of the Asia Pacific Economy, 22(2), 330-352. https://doi. org/10.1080/13547860.2017.1292768 Retrieved September 28, 2019.

Alavi, A., Shokri, M., Zhiani, B., \& Zhiani, S. (2020). Analysing competitive advantage of Iranian automotive industry using Porter's diamond model, case study: Iranian car manufacturers. International Journal of Business and Systems Research, 14(3), 298-313. https://doi.org/10.1504/IJBSR.2020.108269

Bair, J., Anner, M., \& Blasi, J. (2020). The political economy of private and public regulation in post-Rana Plaza Bangladesh. ILR Review, 73(4), 969-994. https://doi.org/10.1177/0019793920925424

Bari, M. S., \& Jin, B. E. (2021). Understanding apparel brand evolution patterns in Bangladesh: An industry life cycle perspective. Journal of Fashion Marketing and Management: An International Journal, 25(3), 548-566. https://doi.org/10.1108/ JFMM-06-2020-0118

BGMEA. (2021b). General Member List. Retrieved February 24, 2021, from BGMEA: https://www.bgmea.com.bd/page/member-list.

BGMEA. (2021a). Export Performance List. Retrieved February 24, 2021, from BGMEA: https://www.bgmea.com.bd/page/exportperformance-list.

Bhattacharya, D., \& Rahman, M. (2000). Experience with Implementation of WTO-ATC and Implications for Bangladesh (No. 7). Dhaka: Centre for Policy Dialogue (CPD). Retrieved September 29, 2019, from https://cpd.org.bd/pub_attach/op7.pdf

Bhuyan, M. I., \& Oh, K. Y. (2021). Exports and inequality: evidence from the highly concentrated textile and garment sector of Bangladesh. Journal of South Asian Development, 16(2), 293-309. https://doi.org/10.1177/09731741211024870

Chandra, S., \& Ferdaus, J. (2020). Contribution of ready-made garments industry on the economic development of Bangladesh: an empirical analysis. Economics, 7(2), 295-307. https://doi.org/10. 18488/journal.29.2020.72.295.307

Creswell, J. W. (2014). Research Design: Qualitative, Quantitative and Mixed Methods Approaches (4th ed.). Sage.

Das, T., Barua, U., \& Ansary, M. (2018). Factors affecting vulnerability of ready-made garment factory buildings in Bangladesh: An assessment under vertical and earthquake loads. International Journal of Disaster Risk Science, 9, 207-223. https://doi.org/10. 1007/s13753-018-0177-6

Evans, C., \& Lewis, J. (2018). Analysing semi-structured interviews using thematic analysis: Exploring voluntary civic participation among adults (pp. 1-6). SAGE Publications Limited. https://doi. org/10.4135/9781526439284 
Export Promotion Bureau. (2019). Retrieved from Export Promotion Bureau of Bangladesh: http://www.epb.gov.bd/.

Francis, J. J., Johnston, M., Robertson, C., Glidewell, L., Entwistle, V., Eccles, M. P., \& Grimshaw, J. M. (2010). What is an adequate sample size? Operationalizing data saturation for theory-based interview studies. Psychology Health, 25, 1229-1245. https://doi. org/10.1080/08870440903194015

Halife, H. (2020). Analysis of Competitiveness of Turkish Textile Sector Based on The Porter's Diamond Model. Stratejik Yönetim Araştırmaları Dergisi, 3(1), 27-49. Retrieved from https://dergi park.org.tr/en/pub/syad/issue/53503/691702.

Hasan, I., Islam, M. N., \& Khan, S. R. (2020). Ready-made garment industry attractiveness: The case of Bangladesh garments' bluecollar employees. International Journal of Emerging Markets. https://doi.org/10.1108/IJOEM-03-2019-0232

Hossian, M. S., Kabir, R., \& Latifee, E. H. (2019). Export competitiveness of Bangladesh readymade garments sector: challenges and prospects. International Journal of Research in Business and Social Science, 8(3), 45-63. https://doi.org/10.20525/ijrbs.v8i3. 205

Islam, M. S. (2021). Ready-made garments exports earning and its contribution to economic growth in Bangladesh. GeoJournal, 86(3), 1301-1309. https://doi.org/10.1007/s10708-019-10131-0

Jin, B., \& Moon, H.-C. (2006). The diamond approach to the competitiveness of Korea's apparel industry. Journal of Fashion Marketing and Management, 10(2), 195-208. https://doi.org/10.1108/13612 020610667504

Kathuria, L. (2013). Analyzing competitiveness of clothing export sector of India and Bangladesh. Competitiveness Review: An International Business Journal, 23(2), 131-157. https://doi.org/10.1108/10595 421311305343

Koty, A. C., \& Zhou, Q. (2019, October 15). Minimum Wages in China 2019. Retrieved from China Briefing: https://www.china-briefing. com/news/minimum-wages-china-2019/.

Lavassani, K. M., \& Movahedi, B. (2021). Firm-level analysis of global supply chain network: role of centrality on firm's performance. International Journal of Global Business and Competitiveness, 16, 86-103. https://doi.org/10.1007/s42943-021-00026-8

Liu, Y. (2021). Hong Kong's cultural and creative industrial—an analysis from the perspective of "Porter Diamond Model." International Conference on Economics, Management Engineering and Education Technology. https://doi.org/10.25236/icemeet.2021.049

Liu, X., Mishra, A., Goldstein, S., \& Sinha, K. (2019). Toward improving factory working conditions in developing countries: An empirical analysis of Bangladesh ready-made garment factories. Manufacturing \& Service Operations Management, 21(2), 379-397. https://doi. org/10.1287/msom.2017.0679

McGrath, C., Palmgren, P. J., \& Liljedahl, M. (2019). Twelve tips for conducting qualitative research interviews. Medical Teacher, 41(9), 1002-1006. https://doi.org/10.1080/0142159X.2018.1497149

Menzel, A., \& Woodruff, C. (2021). Gender wage gaps and worker mobility: evidence from the garment sector in Bangladesh. Labour Economics. https://doi.org/10.1016/j.labeco.2021.102000

Momaya, K. (2001). International Competitiveness: Evaluation and Enhancement. Hindustan Publishing Corporation.

Momaya, K. S. (2019). The past and the future of competitiveness research: a review in an emerging context of innovation and EMNEs. International Journal of Global Business and Competitiveness, 14, 1-10. https://doi.org/10.1007/s42943-019-00002-3

Mostafa, R., \& Klepper, S. (2018). Industrial development through tacit knowledge seeding: Evidence from the Bangladesh garment industry. Management Science, 64(2), 613-632. https://doi.org/10.1287/ mnsc. 2016.2619

Mottaleb, K. A., \& Sonobe, T. (2011, October). An Inquiry into the Rapid Growth of the Garment Industry in Bangladesh. Economic
Development and Cultural Change, 60(1), 67-89. doi:https://doi. org/10.1086/661218.

Nadiruzzaman, M., Rahman, M., Pal, U., Croxton, S., Rashid, M. B., Bahadur, A., \& Huq, S. (2021). Impact of climate change on cotton production in Bangladesh. Sustainability, 13(2), 574. https://doi.org/ 10.3390/su13020574

Parameswaran, U., Ozawa-Kirk, J., \& Latendresse, G. (2019). To live (code) or to not: A new method for coding in qualitative research. Qualitative Social Work, 19(4), 630-644. https://doi.org/10.1177/ 1473325019840394

Paul, R. (2018, September 13). Bangladesh raises wages for garment workers. Retrieved from Reuters.com: https://www.reuters.com/artic le/us-bangladesh-garments/bangladesh-raises-wages-for-garmentworkers-idUSKCN1LT2UR.

Porter, M. (1990). The competitive advantage of nations. Harvard Business Review, 68(2), 73-93.

Rahman, S. (2021). The Bangladesh garment industry and the global supply chain: choices and constraints of management. Routledge. https://doi.org/10.4324/9781003153238

Rahman, N., \& Anwar, J. (2007). The sustainability of RMG as a globally competitive industry: Porter diamond perspective. Journal of Business Studies, 28(2). https://ssrn.com/abstract=1152095

Rasel, M., Das, D., \& Khan, M. (2020). Current scenario of textile sector in Bangladesh (2019); A comprehensive review. International Journal of Innovative Studies in Sciences and Engineering Technology (IJISSET), 6(1), 52-55. ISSN 2455-4863.

Saldana, J. (2016). The coding manual for qualitative researchers. Sage.

Tavory, I. (2020). Interviews and inference: Making sense of interview data in qualitative research. Qualitative Sociology, 43(4), 449-465. https://doi.org/10.1007/s11133-020-09464-x

Tsai, P. H., Chen, C. J., \& Yang, H. C. (2021). Using porter's diamond model to assess the competitiveness of Taiwan's solar photovoltaic industry. SAGE Open, 11(1), 2158244020988286.

Uddin, M. (2014). How Bangladeshi Ready Made Garment Industry can be competitive in the global market. https://urn.fi/URN:NBN:fi:amk2014090113682.

Wang, Y., \& Li, L. (2020). Analysis of competitiveness of high-tech industry in Nanjing based on Porter Diamond Model. Destech Transactions on Engineering and Technology Research MCAEE. https:// doi.org/10.12783/dtetr/mcaee2020/35096

Yunus, M., \& Yamagata, T. (2012). The garment industry in Bangladesh. Dynamics of the Garment Industry in Low Income Countries: Experience of Asia and Africa, chapter 6. Retrieved September 28, 2019, from https://pdfs.semanticscholar.org/e77b/bea34abdf7d935a2439d 4ff031cd73f8dcf3.pdf.

Zaman, S. (2021). Researching the garment sector in Bangladesh: fieldwork challenges and responses. Field Guide for Research in Community Settings. Edward Elgar Publishing. https://doi.org/10.4337/ 9781800376328.00013

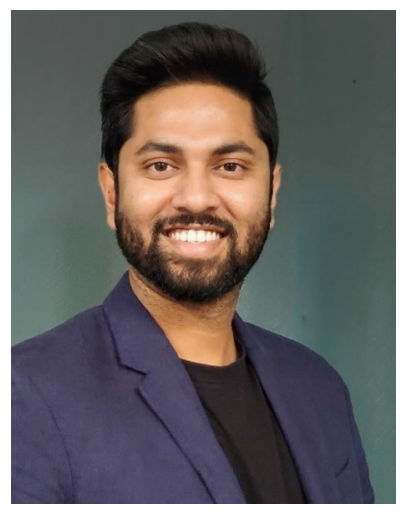

Ishtehar Sharif Swazan is a master's student in the department of Fashion Dress and Merchandising (FDM) at West Virginia University, USA with a major in Design and Merchandising. $\mathrm{He}$ completed his Bachelor's degree in Apparel Manufacturing Technology from Ahsanullah University of Science and Technology, Bangladesh. His research interests include labor welfare, international trade policies, small and micro-business, and consumer behavior. 


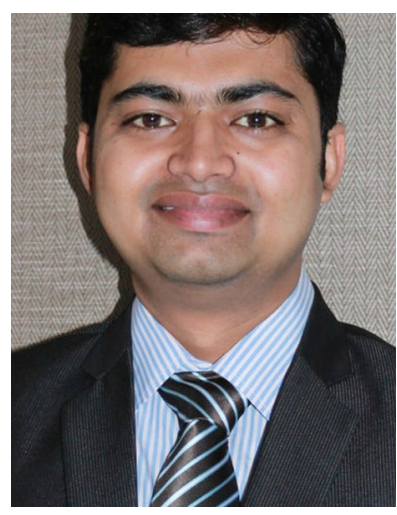

Debanjan Das is an assistant professor at the Fashion, Dress and Merchandising department in the School of Design and Community Development, West Virginia University. He earned his Doctorate and Master's from the University of Missouri. His research program explores the apparel industry from the social, economic and humane viewpoint. His research program investigates the human factor of the industry, social sustainability, small fashion business competitiveness and fashion industry labors issues. 